\title{
VARIASI POLA VOKALISASI PADA TAKSONOMI ANAK JENIS ELANG-ULAR (Spilornis cheela) DI PKEK, GARUT, JAWA BARAT
}

\author{
Devi Fauzia Dermi ${ }^{1 *}$, Agung Seday ${ }^{1}$, Ratna Komala ${ }^{1}$ \\ Program Studi Biologi FMIPA Universitas Negeri Jakarta (UNJ). Jl. Pemuda No. 10 Rawamangun, Jakarta \\ Timur. Indonesia.
}

*Corresponding Email: devifauziadermi@gmail.com.

\begin{abstract}
Crested serpent eagle (Spilornis cheela) is a bird of prey with distinctive of uniue vocal. Based on several studies mentioned that there are differences in vocalization at the level of subspecies and is often used to study the role vocalization defining the subspecies in taxonomy. This research aimed to determine the role variation of vocalization pattern in taxonomy on subspecies eagle. The research was conducted from May to September 2017 at Kamojang Eagle Conservation Center. The method used is descriptive method with continuous sampling technique. The samples was an adult eagle from three subspecies serpent eagle. The location of observation determined by purposive sampling with the provisions listening post is less than 5 meters until 30 meters. The data is collected at 7 am to $5 \mathrm{pm}$. Data were analyzed using sound analysis software. The data taken are fundamental frequency, maximum frequency (MinF), minimum frequency (MinF) and duration. Differences between subspecies were analyzed using Kruskal Wallis and Mann-Whitney $U$ statistical test with SPSS 17.0. The result of the research is The vocalizations can be utilized in the subspecies eagle taxonomy of the species to complement the morphological data, marked by significantly different results on each parameter of vocalization between (Spilornis cheela malayensis) and (Spilornis cheela natunensis). MaxF significantly different in (Spilornis cheela malayensis) and (Spilornis cheela bido), (Spilornis cheela natunensis) and (Spilornis cheela bido).
\end{abstract}

Keywords: Conservation, Kamojang, Serpent Eagle, Vocal Behavior

\section{PENDAHULUAN}

Elang-ular termasuk anggota kelompok burung raptor dengan nama ilmiah Spilornis cheela yang memiliki 26 anak jenis yang tersebar di kawasan Indomalayan atau Paleartik. Sebagian besar tersebar dari sub kontinen, termasuk Himalaya, Pakistan, Kashmir, dan Nepal Timur melalui Tibet, China Selatan (Hunnan), dan melalui Indochina, semenanjung Malaysia dan Filipina (Palawan) juga termasuk Indonesia. Dari 26 anak jenis elang-ular, 16 anak jenis diantaranya terdapat di Indonesia dengan mayoritas merupakan satwa endemik (Ferguson, 2001).

Elang-ular sering terlihat terbang tinggi dan membuat suara yang khas. Suara yang dihasilkan oleh elang-ular terdengar keras, nyaring dan melengking saat terbang di atas pohon atau saat saling memanggil pasangan (Mackinnon, 2010). 
Vokalisasi elang-ular merupakan salah satu bentuk komunikasi yang sangat penting bagi elang-ular (Del Hoyo et al., 1994), untuk bertukar informasi antar satu sama lain secara efektif dengan menggunakan sinyal saat berkomunikasi. Pada vertebrata, komunikasi umumnya dilakukan secara vokalisasi yaitu pemberian sinyal berupa suara. Vokalisasi digunakan satwa untuk memberi informasi mengenai keberadaan kelompok, panggilan untuk makan, memberi peringatan pada kelompok (alarm call), sinyal yang memprediksi perilaku, menarik pasangan, dan mempertahankan teritorial (Seyfarth et al., 2010). Vokalisasi merupakan pendahuluan untuk memahami perilaku bersuara dalam hal perubahan musim dan geografis (Huang et al., 2014). Diantara semua vertebrata, mamalia dan burung memiliki vokalisasi yang lebih berkembang jika dibandingkan dengan kelompok lain (Maida, 2016).

Banyak penelitian mengenai perilaku bersuara hanya difokuskan pada jenis passerine atau burung berkicau, sedangkan penelitian yang difokuskan pada vokalisasi raptor relatif sedikit (Thorstrom et al., 1997). Menurut Harvey dan Pagel (1991) dalam Catchpole dan Slater (1995), perilaku bersuara atau vokalisasi saat ini sering dipergunakan untuk menguji suatu hipotesis mengenai perbedaan jenis dalam grup taksonomi. Menurut Catchpole dan Slater (1995), vokalisasi pada burung dianggap sebagai komponen utama dalam pengakuan jenis.

Beberapa penelitian menunjukan adanya perbedaan perilaku bersuara (vokalisasi) pada banyak organisme yang dapat dimanfaatkan sebagai penanda taksonomi sebagai pelengkap bagi data morfologi (Matessi et al., 2000 dan Liu et al., 2008). Namun, menurut banyak kasus, anak jenis sangat mirip morfologi eksternalnya dan hanya terlihat perbedaan yang nyata pada vokalisasi mereka (Irwin, 2000 dan Brambilla et al., 2008). Selain data morfologi, peneliti juga menggunakan data vokalisasi sebagai penanda filogenetik, seperti yang dilakukan McCracken dan Sheldon (1997), pada beberapa vokalisasi burung.

PKEK atau Pusat Konservasi Elang Kamojang saat ini memiliki tiga anak jenis elang-ular. Ketiga anak jenis ini memiliki deskripsi morfologi yang berbeda satu sama lain dan akan sangat menarik apabila perbedaan morfologi juga terjadi sejalan dengan perbedaan pada vokalisasi, sehingga data vokalisasi akan memperkuat data perbedaan morfologi yang akan mempertegas mengenai pembagian anak jenis dalam taksonomi. Ketiga anak jenis ini diperoleh pusat konservasi elang kamojang berdasarkan hasil sitaan maupun penyerahan sukarela dari warga sekitar Jawa Barat dan yang menjadi masalah, dari ketiga anak jenis ini ada yang tidak umum berada di Jawa Barat, selain itu belum ada penelitian tentang perilaku bersuara dari anak jenis elang-ular khususnya pada pusat-pusat penyelamatan satwa.

Berdasarkan uraian diatas, maka dibutuhkan penelitian mengenai variasi pola vokalisasi pada taksonomi anak jenis elang-ular, karena studi tentang vokalisasi anak jenis elang-ular belum banyak dilakukan, sehingga sangat baik untuk memulai suatu penelitian terhadap anak jenis elang-ular yang diharapkan dapat mengetahui sampai sejauh mana perbedaan yang mereka miliki. Penelitian ini diharapkan dapat mempertegas status taksonomi juga menjadi acuan dalam membantu usaha konservasi dari anak jenis elang-ular.

\section{METODOLOGI PENELITIAN}

\section{TEMPAT DAN WAKTU}

Penelitian ini dilaksanakan di Pusat Konservasi Elang Kamojang, Garut, Jawa Barat, pada bulan Februari Mei 2017.

\section{ALAT DAN BAHAN PENELITIAN}

Alat penelitian yang digunakan diantaranya adalah binokuler, jam tangan, alat rekam kamera prosumer Nikon 
Coolpix L820 dan Nikon P610, laptop yang telah terinstal software sound analysis. Bahan yang dipakai yaitu tiga anak jenis elang-ular.

\section{METODE PENELITIAN}

Metode penelitian yang digunakan yaitu metode deskriptif dengan teknik survey. Pengamatan perilaku bersuara elang-ular dilakukan dengan metode continuous sampling (Altmann, 1974), dimana aktivitas bersuara dan perilaku elang-ular direkam secara terus menerus selama batas waktu yang ditentukan.

Prosedur Penelitian

1. Menentukan Sampel

Penentuan sampel dengan metode purposive sampling berdasarkan ketentuan burung yang bersuara yaitu: Lima ekor Elang-Ular Bido yang tersebar di (Jawa). Satu ekor Elang-Ular Malaya (Sumatera). Satu ekor Elang-Ular Natuna (Natuna). Total ada tujuh ekor dengan seluruh individu yang direkam vokalisasinya adalah individu dewasa dan berjenis kelamin betina.

2. Menentukan Listening post

Listening post (LPs) atau pos pendengaran ditentukan secara purposive sampling dengan ketentuan listening post berjarak kurang dari 5 meter sampai dengan 30 meter dari objek agar vokalisasi dapat terekam dengan jelas. Lima meter ditentukan sebagai jarak maksimal elang merasa terganggu dan tigapuluh meter merupakan jarak minimal elang tidak merasakan gangguan dan mengabaikannya dilihat dari perilaku elang tersebut.

\section{Pengambilan Data Vokalisasi}

Perekaman vokalisasi dari sampel anak jenis elang-ular dilakukan antara pukul 07.00 hingga 17.00 untuk melihat situasi dan pada kondisi apa sajakah elang-ular melakukan vokalisasi sebagai dasar menentukan tipe-tipe vokalisasi pada elang-ular. Vokalisasi direkam menggunakan kamera prosumer Nikon Coolpix L820 dan Nikon P610.

\section{TEKNIK ANALISIS DATA}

Hasil vokalisasi diklasifikasikan sesuai dengan tipe vokalisasi yang diamati saat elang mengeluarkan suara secara deskriptif menggunakan software Raven Lite 2.0 yang sebelumnya data vokalisasi dikonversi dari format mp3 ke format wav menggunakan Any Video Converter. Hasil yang diperoleh adalah berupa sonogram vokalisasi elangular dengan sumbu X yaitu durasi dan sumbu Y yaitu frekuensi $(\mathrm{Hz})$. Dari sonogram tersebut dibaca berapa nilai frekuensi fundamental $(\mathrm{kHz}), \operatorname{MinF}(\mathrm{kHz}), \operatorname{MaxF}(\mathrm{kHz})$, dan durasi $(\mathrm{ms})$ dari pola vokalisasi yang terbentuk.

Hasil dianalisis menggunakan program SPSS 17.0 untuk melihat perbedaan rata-rata antara anak jenis dari elang-ular. Penelitian ini akan berusaha untuk membandingkan tiap tipe vokalisasi terhadap ketujuh sampel anak jenis elang-ular.

\section{HASIL DAN PEMBAHASAN}

\section{POLA VOKALISASI ELANG-ULAR}

Elang-ular memiliki lebih dari satu pola vokalisasi. Tidak seperti burung pengicau vokalisasi elang-ular hanya berupa pangilan yang berulang-ulang serta terdengar seperti serakan atau teriakan seperti yang dikatakan oleh

Ferguson (2001), Crested Serpent-eagle (Spilornis cheela) dari Asia Tenggara termasuk kedalam Scream. Menurut 
Catchpole dan Slater (1995) dalam Fitri (2002), vokalisasi burung dibagi menjadi 2 yaitu, yaitu kicau sederhana atau (call) dan kicau kompleks yang lebih sering disebut sebagai nyanyian atau (song). Vokalisasi elang-ular ini termasuk kedalam call atau kicau sederhana. Pada penelitian ini hasil yang teramati dari pola vokalisasi pada elang-ular akan dibahas sebagai berikut:

\section{Elang-Ular Bido}

Pada dasarnya tiap individu memiliki suara khasnya masing-masing, dari hasil didapatkan 13 pola vokalisasi yang dimiliki oleh elang-ular bido, namun peneliti mengelompokkan vokalisasi elang-ular bido dengan bentuk dasar pola panjang dan pola pendek. Sesuai dengan Zubair et al., (2013) menyebutkan, vokalisasi falcons baik dewasa maupun muda bisa dikelompokkan menjadi dua jenis yaitu: long calls dan short calls. Pola panjang merupakan pola vokalisasi dengan bentuk garis memanjang baik sejajar maupun tidak sejajar. Menurut Zann (1996) Pola panjang pada burung zebra finches dewasa merupakan panggilan terbaik untuk dipelajari yang berupa suara paling keras yang divokalisasikan burung zebra bila seekor burung diisolasi atau merespon burung lain dari jauh maka long call ini disebut juga kontak panggilan.

Elang-ular bido memiliki 7 pola panjang. Pada saat pengamatan pola (A) terdengar seperti "eeaaakkk" ini divokalisasikan dengan mengangkat sedikit bulu-bulu di sekitar kepalanya. Pola (B) terdengar "eeeeee" tanpa mengangkat bulu-bulunya. Mengangkat bulu, tarian, postur tubuh merupakan tampilan visual terkait vokalisasi (Morris, 1954). Pola (C) dan (D) seperti pola (A) elangpun mengangkat lebih tinggi bulu yang berada di sekitar kepalanya dan sedikit di leher, sedangkan pola (D) saat divokalisasikan, elang berjalan mendekati peneliti dengan posisi bulu disekitar kepalanya tetap berdiri. Panggilan ini terdengar seperti memohon atau menarik perhatian peneliti yang saat itu tidak terlalu fokus kepadanya.

Panggilan yang terdengar seperti memohon atau disebut begging/submissive chick-like vocalizations Ramanujam (2000) menyebutkan bahwa, panggilan ini vokalisasikan ketika owl muda, ketika owl betina diberikan makanan oleh owl jantan. Sepertinya elang tersebut mengeluarkan panggilan ini dikarenakan merasa lapar setelah hari sebelumnya tidak diberikan pakan, satu hari dalam seminggu elang dibiasakan berpuasa dengan tidak diberi pakan untuk menyesuaikan dengan keadaan dialam yang tidak setiap hari elang berhasil mendapatkan mangsa. Pola (F) biasanya divokalisasikan saat elang didekati orang, baik dengan peneliti maupun dengan pengunjung yang jumlahnya sedikit tidak dalam rombongan besar. Pola (G) selalu divokalisasikan saat keeper datang baik untuk membersihkan, memberi makan atau hanya sekedar menghampiri. Perilaku yang dilakukan elang adalah mengangkat bulu-bulu di belakang kepalanya selain itu bergerak gelisah dan menghindar. Pola (F) dan (G) divokalisasikan biasanya pada pagi hari saat jam pemberian pakan.

Pola pendek merupakan pola vokalisasi dengan berbagai bentuk note. Note sendiri adalah satuan unit suara yang dikeluarkan individu yang memiliki durasi pendek dan dapat terdiri dari satu pulse atau bisa terdiri dari beberapa pulse (Littlejohn, 1977). Elang-ular bido memiliki 6 pola pendek. Pola (H), pada elang-ular bido terdengar seperti bunyi kokokan dengan nada meninggi diakhir. Pada saat divokalisasikan elang biasanya akan menghampiri dan terkesan seperti menantang, panggilan dengan sikap tersebut sesuai dengan yang dikatakan oleh Zann (1985), panggilan untuk menunjukkan niat untuk menggantikan atau menyerang disebut panggilan agonistik. Pada hasil pengamatan pola vokalisasi elang-ular bido dilakukan secara individual juga saling bersautan dengan elang-ular natuna yang merespon, hal tersebut dikarenakan elang-ular bido mengira elang-ular natuna yang sedang berburu di kandangnya ingin menyerang dan elang-ular natuna merasa elang-ular bido ingin merebut mangsanya. Pola tersebut divokalisasikan elang tidak hanya kepada sesama elang, namun juga kepada peneliti. 
Pola (I) (J) dan (K), elang datang menghampiri dan seperti menunjukan rasa penasaran dengan memiringkan kepala. Pola (L) terdengar "piek" dengan singkat. Pola (M) terdengar "pek pik" pendek. Vokalisasi-vokalisasi tersebut dikeluarkan elang pada saat posisi perching baik di tenggeran maupun saat elang berada di tanah.

Kebanyakan vokalisasi diperoleh pada saat elang merasakan adanya gangguan, gangguan disini yaitu dari keberadaan manusia. Tidak didapati elang melakukan vokalisasi saat elang yang berada di luar terbang melintasi areal kandang pengamatan. Interaksi antar satu anak jenis yang ditempatkan pada satu kandang yang sama juga tidak memberikan hasil berupa vokalisasi. Interaksi antar anak jenis yang berbeda dan ditempatkan pada satu kandangpun tidak memperoleh hasil vokalisasi, sedangkan interaksi antar anak jenis yang berbeda dengan kandang yang bersebelahan didapatkan yakni antara Elang-Ular Bido dan Elang-Ular Natuna.

\section{Elang-Ular Malaya}

Pengamatan vokalisasi elang-ular malaya didapatkan 4 pola vokalisasi, keempat pola tersebut dikatagorikan sebagai pola panjang. Pola (N), (O) dan (P) merupakan pola yang biasa di vokalisasikan elang pagi hari ketika keeper datang untuk memberi pakan, dan pola-pola ini merupakan pola yang paling sering divokalisasikan oleh elang-ular malaya, sedangkan pola $(\mathrm{Q})$ merupakan pola vokalisasi yang paling jarang terdengar hanya tercatat 3 kali elang memvokalisasikan pola tersebut yaitu, dua kali ketika berhadapan dengan peneliti dan satu kali dengan pengunjung. Saat pengamatan tidak teramati elang-ular malaya melakukan vokalisasi diwaktu-waktu tertentu. Apabila tidak ada gangguan elang lebih banyak diam sambil menelisik di tenggerannya.

\section{Elang-Ular Natuna}

Elang-ular natuna ditemukan juga pola panjang dan pola pendek. Terdapat 2 pola panjang pada vokalisasi elangular natuna. Pola panjang vokalisasi elang-ular natuna merupakan nada dengan tekanan nyaring dan melengking. Pola $(\mathrm{R})$ terdiri dari dua lengkingan sedangkan pola $(\mathrm{S})$ terdiri dari tiga lengkingan, diduga kedua pola tersebut merupakan penanda vokalisasi sebagai intimidasi dan keseluruhan vokalisasi dari elang-ular natuna termasuk "aggression call" yang ditandai dengan perilaku elang yang mendekati, mengejar bahkan sampai menyerang walaupun terhalang oleh jaring, elang sering teramati mematuk dan mencakar jaring kandang sampai rusak dan berlubang. Ramanujam (2000), menyebutkan aggression call adalah bunyi yang merespon gangguan. Suara dari paruh yang terbuka dan digunakan oleh burung dengan segala usia. Vokalisasi ini selalu disertai dengan sikap intimidasi dan agonistik dan menurut Burton (1973), vokalisasi ini nampak umum untuk kebanyakan jenis raptor.

Selama pengamatan hanya aggression call saja yang terlihat divokalisasikan sebagai respon elang menyadari kehadiran manusia dan juga ketika merasa terganggu oleh elang lainnya. Elang-ular natuna memiliki 3 pola pendek. Pola ini berupa kokokan dengan bunyi dua dibagian akhir meninggi.

\section{PERBEDAAN PARAMETER VOKALISASI ELANG-ULAR}

Hasil uji dapat dilihat pada Tabel 1 di bawah ini. Statistik yang digunakan yaitu metode statistika non parametrik uji Kruskal Wallis yang kemudian dilanjutkan dengan uji Mann-Whitney U Test menggunakan aplikasi (Statistical Package for the Social Sciences) SPSS 17.0. Pada penelitian ini semua parameter berbeda nyata $(\alpha<0,05)$.

Berdasarkan hasil fundamental menunjukan elang-ular malaya memiliki peringkat rata-rata yang paling tinggi diikuti elang-ular bido kemudian elang-ular natuna yang terendah. Pada maxf peringkat rata-rata yang paling tinggi yaitu elang-ular malaya dan yang terendah yaitu elang-ular bido, namun sebaliknya pada minf elang-ular bido yang tertinggi dan elang-ular malaya yang terendah. Elang-ular natuna memiliki peringkat tertinggi pada durasi daripada kedua anak jenis elang-ular lainnya. 
Tabel 1. Rata-rata nilai parameter vokalisasi anak jenis elang-ular

\begin{tabular}{|c|c|c|c|c|c|}
\hline \multirow{2}{*}{ Parameter } & \multicolumn{3}{|c|}{ Mean Rank anak jenis } & \multirow{2}{*}{$\begin{array}{c}\text { Uji } \\
\text { Kruskal } \\
\text { Wallis }\end{array}$} & \multirow[b]{2}{*}{$P$} \\
\hline & Malaya & Natuna & bido & & \\
\hline Fundamental $(\mathrm{kHz})$ & 638,93 & 289,08 & 618,80 & 135,002 & $0,000 *$ \\
\hline$M a x F(\mathrm{kHz})$ & 791,51 & 651,27 & 536,52 & 65,916 & $0,000^{*}$ \\
\hline $\operatorname{Min} F(\mathrm{kHz})$ & 393,09 & 576,05 & 597,61 & 36,715 & $0,000^{*}$ \\
\hline Durasi (ms) & 476,35 & 852,18 & 539,56 & 128,051 & $0,000 *$ \\
\hline
\end{tabular}

\section{Keterangan:}

\section{* = Signifikan pada $\mathrm{p}<0,05$}

Pada tabel 2 terlihat bahwa antara elang-ular malaya dengan elang-ular natuna terdapat perbedaan yang signifikan $(\mathrm{p}<0,05)$ dari keempat parameter dan antara elang-ular malaya dengan elang-ular bido tidak terdapat perbedaan yang signifikan pada fundamental dan durasi, sedangkan antara elang-ular natuna dan elang-ular bido tidak berbeda secara signifikan $(\mathrm{p}>0,05)$ hanya pada minf saja. Dari keempat parameter hanya maxf yang berbeda secara signifikan antar anak jenis.

Tabel 2. Hasil uji Mann-Whitney mengenai perbedaan parameter vokalisasi antara anak jenis elang-ular

\begin{tabular}{|c|c|c|c|c|c|c|}
\hline \multirow{3}{*}{ Parameter } & \multicolumn{6}{|c|}{ Anak Jenis } \\
\hline & Malaya & \multirow{2}{*}{$P$} & Malaya & \multirow{2}{*}{$P$} & Natuna & \multirow{2}{*}{$P$} \\
\hline & Natuna & & Bido & & Bido & \\
\hline \multirow{2}{*}{$\begin{array}{c}\text { Fundamental } \\
(\mathrm{kHz})\end{array}$} & 168,27 & \multirow{2}{*}{$0,000 *$} & 525,16 & \multirow{2}{*}{0,298} & 259,85 & \multirow{2}{*}{$0,000 *$} \\
\hline & 107,73 & & 494,69 & & 568,11 & \\
\hline \multirow[t]{2}{*}{$\operatorname{Max} F(\mathrm{kHz})$} & 145,06 & \multirow{2}{*}{$0,026^{*}$} & 700,95 & \multirow{2}{*}{$0,000^{*}$} & 605,96 & \multirow{2}{*}{$0,000 *$} \\
\hline & 123,80 & & 473,29 & & 507,23 & \\
\hline \multirow[t]{2}{*}{$\operatorname{Min} F(\mathrm{kHz})$} & 94,15 & \multirow{2}{*}{$0,000 *$} & 353,44 & \multirow{2}{*}{$0,000 *$} & 495,67 & \multirow{2}{*}{0,246} \\
\hline & 158,37 & & 515,60 & & 526,01 & \\
\hline \multirow[t]{2}{*}{ Durasi (ms) } & 63,76 & \multirow{2}{*}{$0,000^{*}$} & 467,09 & \multirow{2}{*}{0,236} & 750,59 & \multirow{2}{*}{$0,000^{*}$} \\
\hline & 180.09 & & 501,76 & & 481,80 & \\
\hline
\end{tabular}

Berdasarkan hasil penelitian ini diketahui terdapat variasi pola vokalisasi pada ketiga anak jenis elang-ular dimana adanya variasi merupakan salah satu dasar selain karakter dan bentuk morfologi. Untuk memecahkan permasalahan taksonomi Lumowa dan Sonja (2012) menyatakan, diperlukan sumber bukti taksonomi seperti morfologi, anatomi, embriologi, sitologi, paleologi, ekologi, fisiologi, juga biogeografi.

Hasil uji pada tabel 2 diperoleh bahwa pada elang-ular malaya yang tersebar di pulau Sumatra dengan elang- 
ular natuna yang persebarannya terletak di pulau Natuna walaupun jarak antar pulau berdekatan keduanya memiliki variasi yang jelas berbeda secara nyata pada semua parameter, sedangkan pada elang-ular malaya dengan elang-ular bido tidak berbeda secara nyata pada parameter fundamental dan durasi maupun elang-ular natuna dengan elangular bido yang tidak berbeda secara nyata pada parameter minf.

Perbedaan variasi yang jelas pada Elang-Ular Malaya dengan Elang-Ular Natuna dalam jarak antar pulau yang berdekatan salah satunya dialami pula oleh White dan Kiff (2000), yang menyatakan dalam penelitiannya bahwa dalam jarak antar pulau pendek mereka menemukan perbedaan morfologi antara Elang-Ular Malaya (Spilornis cheela malayensis) yang berada di Sumatra Utara yang agak gelap warnanya dan lebih besar dengan rata-rata panjang sayap $364 \mathrm{~mm}$ sedangkan $125 \mathrm{~km}$ ke arah barat pulau Nias ditemui elang-ular nias (Spilornis cheela asturinus) dengan warna lebih pucat dan kecil dengan rata-rata memiliki panjang sayap 299 mm. Ferguson dan Christie (2010), dalam bukunya menuliskan elang-ular natuna dan elang-ular nias dipisahkan menjadi spesies tersendiri.

Hal tersebut sejalan dengan hasil penelitian yang didapatkan, bahwa terlihat jelas berbedaan parameter vokalisasi antara elang-ular malaya dengan elang-ular dikarenakan tidak adanya gene flow yang terjadi antar keduanya (White dan Kiff, 2000). Data parameter vokalisasi dapat digunakan untuk mendukung data morfologi dan dapat dikatakan bahwa telah terjadi pembentukan anak jenis yang sempurna. Namun dari hasil penelitian terlihat pula ternyata, parameter vokalisasi belum berhasil memetakan secara jelas perbedaan elang-ular malaya dengan elangular bido maupun elang-ular natuna dengan elang-ular bido dikarenakan adanya data parameter vokalisasi yang tidak berbeda secara nyata. Artinya, parameter vokalisasi mereka mirip dan dapat berarti bahwa pembentukan anak jenis yang terjadi masih berjalan atau pembentukan anak jenis belum sempurna.

Menurut Widodo (2007), suatu pembentukan spesies baru melalui perkembangbiakan yang terjadi secara natural yang terkait dengan evolusi, dimana keduanya merupakan suatu proses perubahan yang berangsur-angsur, sedikit demi sedikit, secara gradual, perlahan tapi terjadi adalah spesiasi. Menurut Campbell (2003), proses spesiasi ini dapat berlangsung secara cepat atau lama hingga berjuta-juta tahun yang diakibatkan oleh adanyanya isolasi geografi, isolasi reproduksi, dan perubahan genetika.

Bukti yang didapatkan terkait pembentukan anak jenis yang belum sempurna untuk elang-ular malayensis dengan elang-ular bido juga elang-ular natuna dengan elang-ular bido adalah yang pertama bahwa mereka berbeda sedikit secara morfologi dan yang kedua parameter vokalisasi hanya maxf yang menunjukan hasil beda nyata. Namun pandangan lain didapatkan bahwa parameter vokalisasi tidak selalu dapat dimanfaatkan untuk pembagian taksonomi anak jenis, buktinya ada parameter vokalisasi yang tidak berbeda secara nyata pada parameter fundamental, minf dan durasi antar ketiga anak jenis, sehingga pandangan tersebut dapat diabaikan karena pembentukan anak jenis belum sempurna yang menjadikan data parameter fundamental, $\operatorname{minf}$ dan durasi seakan-akan tidak dapat dimanfaatkan.

Hardouin et al., (2007) menyatakan dalam penelitiannya, parameter durasi juga tidak berkorelasi untuk menjabarkan parameter vokalisasi terhadap karakter fisik yaitu berat badan, sedangkan minf berkorelasi pada karakter fisik berat badan tapi tidak dengan ukuran tubuh. Fundamental walaupun mencerminkan perilaku vokalisasi yang dibatasi oleh komponen genetik dan morfologi syiringeal juga menampilkan informasi filogenetik yang lebih informatif dari pada maxf yang menurut Irwin et al., (2007), maxf menunjukan satu faktor yang mempengaruhi bahwa telah terjadi evolusi. Namun, fundamental tidak sepenuhnya terbebas dari homoplasy yaitu kesamaan antara evolusi spesies yang terkena konvergen. Evolusi konvergen adalah seleksi alam yang mendukung struktur jenis yang sama nenek moyang yang berbeda (McCracken dan Sheldon 1997). 


\section{SIMPULAN}

Kesimpulan dalam penelitian ini adalah terdapat variasi dari pola vokalisasi yang dapat dimanfaatkan pada taksonomi anak jenis elang-ular guna melengkapi data morfologi. Variasi ditandai oleh hasil yang berbeda pada setiap parameter fundamental maxf, minf, dan durasi antara elang-ular malaya dengan elang-ular natuna. Elang-ular malaya dengan elang-ular natuna lebih jauh kekerabatannya. Elang-ular bido dengan elang-ular natuna dan elang-ular bido dengan elang-ular malaya lebih dekat kekerabatannya.

\section{UCAPAN TERIMA KASIH}

Terima kasih kepada Balai Besar Konservasi dan Sumber Daya Alam (BBKSDA) seksi wilayah V Garut Provinsi Jawa Barat dan staf pegawai yang telah memberikan perizinan. Terima kasih kepada Bapak Zaini Rakhman (Pemerhati elang dari Raptor Indonesia dan pengelola PKE Kamojang) serta staf yang telah membimbing dan memberi dukungan selama penelitian ini.

\section{DAFTAR PUSTAKA}

Altmann, J. 1974. Observational Study of Behaviour: Sampling Methods. Behaviour. 49(3): 227-67.

Brambilla, M., Janni, O., Guidali, F., dan Sorace, A. (2008). Song perception among incipient species as a mechanism for reproductive isolation. Journal of evolutionary biology, 21(3), 651-657.

Burton JA. 1973. Owls of The World. New York: E.P. Dutton and Co.Inc. 378pp.

Campbell, N.A., Reece, J.B., dan Mitchell, L.G. 2004. Biologi. Jilid 3. Edisi Kelima. Alih Bahasa: Wasmen. Jakarta: Penerbit Erlangga.

Catchpole CK, Slater PJ. 1995. Bird song. Biological themes and variations. Cambridge University Press, Cambridge.

Del Hoyo,J., Elliott, A., Sargatal, J. 1994. Handbook of the Birds of the World. Vol. 2: New World Vultures to Guineafowl. Lynx Edicions, Barcelona.

Ferguson L, J., D.A., Christie. 2001. Raptors of the world. Houghton Mifflin, Boston, MA.

Ferguson L, J., D.A., Christie. 2010. Raptors of the world. Houghton Mifflin, Boston, MA.

Fitri LL. 2002. Panduan Singkat Perekaman dan Analisa Suara Burung. Bandung: Departemen Biologi, Fakultas Matematika dan Pengetahuan Alam, Institus Teknologi Bandung.

Hardouin LA, Reby D, Bavoux C, Bureneleau G, Bretagnolle v. 2007. Communication of male quality in owl hoots. Am. Nat. 169, 552-562.

Huang, YK., Chen, HC., Sun, YH., Chiang, PJ. 2014. Preliminary Study on the Vocal Behavior of Mountain Hawk Eagle Nisaetus nipalensis in Taiwan. Journal of Raptor Research. 43(2):159-163.

Irwin DE. 2000. Song variation in an avian ring species. Evolution. 54:998-1010.

Irwin DE, Thimgan MP, Irwin JH. 2007. Call divergence is correlated with geographic and genetic distance in greenish warblers (Phylloscopus trochiloides): a strong role for stochasticity in signal evolution?. J. Evol. Biol. 21:435-448.

Littlejohn, M. J. 1977. Long range acoustíc communicatíon in anurans: an integrated and evolutíonary approach, in D. H. Taylor and S. I. Curtirían (eds.). The Reproductive Biology of Amfibia. New York: Plenum Press. pp 
263-294.

Lumowa, Sonja V.T. 2012. Bahan Ajar Botani Tingkat Tinggi. Universitas mulawarman: Samarinda.

MacKinnon, J. 2010. Burung- burung di Sumatera, Jawa, Bali, dan Kalimantan. Bogor: Burung Indonesia.

Maida, S. 2016. Variasi Struktur Vokalisasi Owa Jawa (Hylobates moloch Audebert, 1798) di Hutan LIndung Petungkriono, Pekalongaan, Jawa Tengah [Skripsi]. Jakarta: Universitas Negeri Jakarta.

Matessi G, Pilastro A, Marin G. 2000. Variation in quantitative properties of song among European populations of reed bunting (Emberiza schoeniclus) with respect to bill morphology. Can JZool. 78:428-437.

McCracken, Sheldon Frederick H. 1997. Avian vocalizations and phylogenetic signal. Journal of Proc. Natl. Acad. Sci. USA. 94, 3833-3836.

Ramanujam, ME. 2000. An Attempt To Rationalize On The Vocalizations And Displays Of Captive Indian Eagle Owls, Bubo Bubo Bengalensis Franklin. Paper. Zoos' print journal. 15(6): 269-274.

Seyfarth, RM., Dorothy L., Cheney., Thore Bergman., Julia Fischer., Klaus Zuberbuhler., Kurt H. 2010. The central importance of information in studies of animal communication. Essay. Animal behaviour, 80, 3-8.

Thorstrom, R., J. Hart, R. T. Watson. 1997. New record, ranging behaviour, vocalization and food of the Madagascar red owl Tyto soumagnei. Ibis. 139:477-481.

White, C. M., dan Kiff, L. F. (2000). Biodiversity, island raptors and species concepts. Raptor at Risk. WWGBP, Hancock House, 633-652.

Widodo, Pudji. 2007. Spesiasi pada Jambu-Jambuan (Myrtaceae): Model Cepat dan Lambat. Biodiversitas. 8:7982.

Zann RA. 1985. Ontogeny of the Zebra Finch distance call: Effect of cross-fostering to Bengalese Finches. $Z$ Tierpsycol. 68:1-23.

Zann RA. 1996. The Zebra Finch: A synthesis of field and laboratory studies. New York: Oxford UP.

Zubair M, Shukkur E.AA, Azeez P.A. 2013. Vocalization of Lugar, Barbary and Sooty Falcons In The United Arab Emirates. Millenium zoology. 14:53-59. 